\title{
COMPETENCE ORIENTED TECHNOLOGIES IN TEACHING FOREIGN LANGUAGES FOR PROFESSIONAL PURPOSES
}

\section{ЗАСТОСУВАННЯ КОМПЕТЕНТНІСНО ОРІЕНТОВАНИХ ТЕХНОЛОГІЙ ПРИ ВИКЛАДАННІ ІНОЗЕМНОЇ МОВИ ЗА ПРОФЕСІЙНИМ СПРЯМУВАННЯМ}

UDC 378.016:81-13

DOI https://doi.org/10.32843/2663-60852019-14-1-7

\section{Boichuk A.P.,}

Candidate of Pedagogical Sciences,

Senior Lecturer at the Department

of Foreign Languages,

Vasyl Stefanyk Precarpathian

National University

Tytun O.L.,

Candidate of Pedagogical Sciences, Associate Professor at the Department of Foreign Languages,

Vasyl Stefanyk Precarpathian

National University

\section{Sivkovych H.M.,}

Candidate of Pedagogical Sciences,

Associate Professor at the Department

of Foreign Languages,

Vasyl Stefanyk Precarpathian

National University
The article outlines the scientific approaches to applying pedagogical innovative technologies in teaching foreign languages for professional purpose; it was revealed the essence of the concept "pedagogical technologies" and its multiplicity and complexity has been proved. Competence oriented technologies are considered as a way to implement a system of successive deployment of educational activities aimed at the future profession and put the personality of the learner in the centre of the entire educational system, assure comfortable, nonconflict and safe conditions for his development and realization of his natural potential. It is stated that during the process of training future specialists by means of the foreign language for professional purposes technologies are similar and classified according to certain features and properties as for goals, content, forms, methods and means of learning. They promote professional mobility and adaptability to socio-economic changes and individual peculiarities of future professionals. All of them are applied at the foreign language lessons according to the topics, goals and requirements specified in the state standard of higher education and foreign language for professional purpose programs. The main tasks and methodical techniques used at the lessons forming foreign language professional competencies have been characterized. The article notes that development of foreign language communication skills by means of learning technologies includes the development of speech, language, socio-cultural, educational and cognitive competences. The main effective methods and interactive forms of education organization have been given and their importance to develop communicative, organizational and professional skills has been defined.

Key words: competence oriented technologies, foreign language for professional purposes, communicative competences, education methods, foreign language communication, professional skills.

У статті окреслені наукові підходи в застосуванні компетентнісно орієнтованих тех- нологій під час викладання іноземної мови за профресійним спрямуванням, визначено сутність поняття «педагогічні технології» та доведена його багатозначність і складність. Компетентісно орієнтовані технологі розглядаються як спосіб реалізації системи послідовного розгортання профресійно орієнтованої навчальної діяльності та ставлять у центр всієї освітньої системи особистість того, хто навчається, забезпечення комфортних, безконсрліктних і безпечних умов його розвитку та реалізації його природного потенціалу. Зазначається, що у процесі підготовки майбутніх фрахівців засобами іноземної мови за професійним спрямуванням навчальні технології за своїми цілями, змістом, фоормами, методами та засобами навчання $\epsilon$ подібними і класисрікуються за певними ознаками та властивостями. Вони сприяють профресійній мобільності й адаптованості до соціально-економічних змін та індивідуальних особливостей майбутніх фрахівців. Усі вони застосовуються на заняттях іноземної мови відповідно до тематики, мети та вимог, які зазначені в державному стандарті вищої освіти та програмах з іноземної мови за профессійним спрямуванням. Охарактеризовано основні завдання та методичні прийоми, які використовуються на заняттях для формування іншомовних професійних компетенцій. У статті наголошується на тому, що розвиток іншомовної комунікативної компетенції засобами навчальних технологій передбачає розвиток мовленнєвої, мовної, соціокультурної, навчально-пізнавальної компетенцій. Наведено основні ефрективні методи й інтерактивні орорми організації навчання, визначено їхнє значення в розвитку комунікативних, організаційних і профресійних навичок.

Ключові слова: компетентісно орієнтовані технології, іноземна мова за професійним спрямуванням, комунікативні компетенції, методи навчання, іншомовне спілкування, просресійні навички.
Introduction. In connection with rapid and radical changes taking place in modern Ukrainian society, the higher education needs to update the content and methods of applying pedagogical innovative technologies in teaching foreign languages. They are the ones meet the needs of upcoming generations, moreover any approaches and style of information presentation are exposed to modernize because of the new opportunities appeared. In this regard it is necessary to direct students' education on the development of solving problems abilities related to their future specialty and to their results presentation by means of foreign languages, that is, the formation of foreign languages professional communication skills.
So, an important task of the professional training by means of foreign languages is the use of teaching competence oriented technologies creating conditions for a new qualitative professional training in compliance with modern market needs.

Theoretical framework and research methods. Technological approaches concerning the professional training organization are considered in the works of such scientists as Y. Babanskyi, V. Bernardchik, V. Bespalko, L. Fridman, T. Kudriavtseva, M. Makhmutova, N. Talyzina, A. Verbytskyi. and other psychologists and educators. The term "pedagogical technology" is used by such scholars as B. Lykhachov, V. Monakhov, P. Pikasystyi, M. Savina, I. Ziaziun. 
Novelty of research. Despite the activity of scientific analysis in the field of professional training the aspects of higher education that are focused on lab our market needs remain insufficiently studied. Such direction of studying as using competence oriented technologies in teaching foreign languages for professional purposes was not the subject of separate conceptual research. Therefore, the relevance of the above mentioned problem and the training of future specialists in accordance with modern requirements and needs is undeniable.

The aim of this study is to consider scientific approaches concerning the application of competence oriented technologies at the lessons of foreign languages for professional purposes.

Results. In accordance with the goal of teaching a foreign language for professional purposes competence oriented technologies are means and methods used for profession oriented foreign language studying. Interactive technologies and teaching methods create the necessary preconditions for the development of students' speech competence, the ability to improve the professional and general culture of communication.

According to terminology dictionaries learning technology is seen as a way of implementing the content of training provided by curricula, that is a system of forms, methods and means of instruction, which provides the most effective achievement of certain educational goals [3, p. 29]. Scientists consider: technology to be an algorithm for the interaction of participants in the educational process, which leads to the achievement of the learning goal; teaching technology to be a scientific discipline that is engaged in the optimization of the didactic process [4].

The term "pedagogical technology" is also used in the field of education. It (education technology) appeared in pedagogical editions in the $1960^{\text {s. In the }}$ United States the journal 'Pedagogical Technology' has been published since 1961, in the United Kingdom there is 'Pedagogical technology as a learning process' published since 1964, in Japan they have "Pedagogical Technology" published since 1965, and the first edition of "Italian Journal of Educational Technology" came to light in 1971. The word "technology" comes from the Greek words techne - skill and logos - doctrine. Therefore, the term "pedagogical technology" is considered as a doctrine of pedagogical art, skill.

There is no unanimity among researchers in the approaches to understanding the concept of "pedagogical technology". In keeping with P. Podkasystyi pedagogical technology is a combination of values, principles, rules in didactic practice [5]. V. Bespalko identifies pedagogical technologies with didactic systems [1]. Pedagogical technologies are considered by O. Kozireva as complex and open systems of methods and techniques united by priority educational and developmental goals, conceptually interconnected tasks, content, forms and methods of the educational process organization, which eventually creates a certain set of conditions for the students development [6]. In accordance with I. Ziaziun the conventional interpretation of pedagogical technology indicates the systematic set and order of functioning of all personal, instrumental and methodological means necessary to achieve pedagogical goals [2].

Summarizing the approaches to the concept of 'pedagogical technology' we can conclude that there are several different positions in understanding and using this term:

- pedagogical technology as the development and application of teaching tools, equipment and means for the educational process;

- pedagogical technology is an organized and purposeful process of pedagogical influence on the educational process;

- pedagogical technology is a new type of teaching aids;

- pedagogical technology is considered as a process of communication or a way of fulfilling an educational task which involves the use of system analysis to improve the quality of the learning process.

Thus, scientists consider pedagogical technology as a systematic method for the creation, application and definition of the whole teaching and learning process taking into account technical and human resources and their interaction, which aims to optimize forms of education. It is believed that pedagogical technology is a collection of reproduction means and methods for theoretically grounded learning and education processes, which allow implementing the educational goal successfully. Pedagogical technology consists of describing the ways of activity (didactic processes), the conditions in which this activity should be implemented (organizational forms of training), and the funds for this activity implementation.

It should be noted that during the process of training future specialists by means of the foreign language for professional purposes technologies are similar and classified according to certain features and properties as for goals, content, forms, methods and means of learning, for example:

- by the essential and instrumentally significant properties;

- by level of application: general-pedagogical, methodical (subject) and local (modular) technologies;

- by the nature of the content and structure: educational, religious, general education and profession oriented, humanitarian and technocratic, branch, subject, complex and mono-technologies;

- by type of organization and management of cognitive activity;

- by categories of those who study: traditional educational technology designed for a sufficient level of the learner's success; advanced technology for 
in-depth study of the subject; technologies of compensatory learning;

- by type of the study goals: information-developing (cognitive) technologies; those ones focused on the constant assimilation of a significant amount of information, the formation of a clear system of knowledge, acquiring and free operation of knowledge;

- by focusing on the development of mental activity (developmental problem education);

- activity technologies focused on mastering the methods of professional and educational activity (contextual studies, modeling of professional activity in the educational process);

- person oriented technologies, aimed at the development of personality, in particular at the formation of personality activity in the educational process.

The process of professional foreign language learning has some difficulties. Teaching "Foreign Language for Professional Purpose" provides for a sufficiently high level of students' language proficiency. That is why competence oriented technologies put the personality of the learner in the center of the entire educational system, assure comfortable, non-conflict and safe conditions for his development and realization of his natural potential.

We consider competence oriented technologies in the training of specialists as a way of implementing a system for the consistent deployment of profession oriented learning activities. It is aimed at outlining the goals set in the context of the market orientation of the educational process for the effective implementation of professional activities, creative self-development and professional self-improvement of future specialists. They also promote professional mobility and adaptability to socio-economic changes and individual peculiarities of future professionals.

So, the desire to improve the quality of knowledge of foreign languages for further professional activities and compliance with the requirements and needs of the modern labor market necessitates the improvement of the educational process using the competence oriented technologies. In turn, they should be aimed at the formation of professional competences, the development of professional motivation, the value perception of their own work results. All of them are applied at the foreign language lessons according to the topics, goals and requirements specified in the educational standard of higher education and foreign language for professional purpose programs. Development of communication skills by means of foreign languages includes the development of speech, language, socio-cultural, educational and cognitive competences.

Scholars emphasize the application of a competence approach in designing a paradigm of modern education. According to the ideas of the competence approach not only the formed competencies have educational value. Mastering the methods of their obtaining, the ability to understand the need for new knowledge, as well as the ability to solve complex situations and tasks quickly, effectively, independently or in conjunction with other people contribute to the future professionals development such qualities as:

- professional motivation;

- professional independence;

- creativity;

- analytical and forecasting abilities in the evaluation of the results of professional activity;

- need for mastering additional professional functions and competencies.

At the present stage the modernization of the teaching foreign languages process for professional purposes in higher education continues as an active search for ways to improve it. Therefore, the involvement of modern competence oriented forms, methods and technologies of training for the improvement of professional communication skills provides the mutual interaction between the theoretical and practical training of students. Effective methods in teaching a foreign language are cases, a method for analyzing problem situations, methodologies for modeling professional situations, study tours, business games, role-playing games. Implementation of interactive forms of training organization (employment-trip, study-excursion, occupation-role-playing game) enables to optimize the process of communicative and organizational skills formation, to reveal the student's personal (creative) potential; to promote the development of personal professional qualities; to bring theoretical knowledge to real professional activity; to use interdisciplinary connections, attracting knowledge from various educational subjects.

These methodical ways of work are used for the students' development of communicative skills getting acquainted them with the peculiarities of linguistic behavior in a particular communicative situation; mastering new lexical and grammatical units; working out the language patterns of typical dialogues individually or in group; learning to respond to certain replies; activating the use of language cliches; conducting dialogues based on the situation in accordance with the theme of the project; conducting discussions on specific topics; learning to make up dialogues and monologues using visual aids; simulating different communication situations. Finally, students present the projects at the student conference.

There are also effective educational methods to form a professional consciousness of future specialists: understanding specific students' worldview concepts; appealing to their emotionally sensual sphere; persuasion on specific examples; the positive qualities of the teachers they are trying to instill in students Such tasks as projects during independent work form the valuable attitude of students for studying and future profession, self-education skills, instills a culture of mental work and prepare for self-improvement 
in the future, promotes a steady need for the acquisition of knowledge, skills and abilities, development of cognitive and research activity.

It should be emphasized that the following tasks are solved at the integrated foreign language lessons:

- development of the ability to read in depth, understanding the original foreign text of professional orientation;

- vocabulary and intense activation of the professional lexical items accumulated in the previous stages of studying;

- development of discussion and communication skills;

- mastering skills of writing professional documentation and improvement of professional qualities.

All of the above methods and learning technologies are mainly aimed at developing the skills of speaking a foreign language, the ultimate goal of which is to achieve professional communicative competences. One of the main tasks of competence oriented technologies is mastering of all foreign language cultural aspects through communication. Moreover communication is used as a method of education, getting knowledge and learning development. The process of teaching foreign language communication is a model of the real communication process in accordance with the following features: motivation, purposefulness, informativeness, novelty, situationality, functionality, the nature of the interlocutors interaction, the system of linguistic means. This creates conditions for communication that is adequate and real. Successful mastering of skills and their use in conditions of real communication is provided.

Conclusions. The increased professional requirements for graduates and the realities of life challenge the teachers for further studying the most effective learning techniques and technologies and implementation them into the training process combining traditional and innovative methods in teaching. Analyzing all the above mentioned we can conclude that there are important teaching methods for the students training at the lessons of foreign language for professional purpose with the use of competence oriented technologies. So, they are:

- reproduction of real working conditions;
- learning market mechanisms in developing modern learning activities;

- professional personality of the future specialist;

- professional motivation;

- development of creativity, professional responsibility and professional independence;

- conformity of organizational teaching forms and means to the content of competence training as for formating personal, methodological and professional competencies.

In addition, educational and production communication tasks should be similar to the real task characterizing specific activities. In our opinion they can be:

- stereotyped tasks with a specific algorithm which involve the execution of tasks in exact accordance with the requirements of specific documents;

- diagnostic tasks which involve the analysis of the situation and the choice of a solution from a certain number of possible predetermined options;

- creative tasks that involve the "originality" of thinking, cognitive activity of a specialist as for an independent choice of method to solve the problems.

Thus, the use of active competence oriented teaching technologies at the lessons of foreign language for professional purpose leads to the development of communicative competences and aims at creating motivation to study foreign languages.

\section{REFERENCES:}

1. Беспалько В. Слагаемые педагогической технологии. Москва : Педагогика, 1989. 192 с.

2. Педагогічна майстерність : підручник / І. Зязюн та ін. ; за ред. І. Зязюна. 2-ге вид. допов. і переробл. Київ : Вища школа, 2004. 422 с.

3. Короткий словник актуальних педагогічних термінів / упор. Н. Флегонтова. Київ : КНУТД, 2013. 55 с.

4. Ортинський В. Педагогіка вищої школи. Види педагогічних технологій. URL: http://pidruchniki. com/17190512/pedagogika/vidi_pedagogichnih_ tehnologiy.

5. Підкасистий П. Педагогіка : навчальний посібник для студентів педагогічних вузів і педагогічних коледжів. Москва : Педагогічне товариство Росії, 1998. $640 \mathrm{c}$.

6. Селевко Г. Современные образовательные технологии. Москва : Народное образование, 1998. 256 c. 